\title{
Parental Expectations and Educational Outcomes for Young African American Adults: Do Household Assets Matter?
}

\author{
Trina R. Williams Shanks • Mesmin Destin
}

Published online: 31 March 2009

(C) Springer Science+Business Media, LLC 2009

\begin{abstract}
African American children are more likely to be poor and live in households that are "asset poor," with no or very little net worth. Using the Panel Study of Income Dynamics and its Child Development Supplement, this article explores whether living in a household with net worth above the sample median seems to promote educational success and the development of human capital over time, irrespective of income. Controlling for parental income and education, as well as gender, household wealth in the form of net worth was the best predictor of parental expectations, high school completion, and college enrollment for young African American adults. A brief discussion of possible asset-building policy options follows.
\end{abstract}

Keywords Assets - Wealth - African Americans . Young adults · Poverty - Educational attainment . Parental expectations - Panel Study of Income Dynamics . PSID Child Development Supplement

When one thinks about breaking intergenerational cycles of disadvantage and creating more opportunities for the next generation, what often comes to mind is helping

T. R. Williams Shanks ( $\square)$

University of Michigan School of Social Work, 1080 S. University, P.O. Box 65, Ann Arbor, MI 48109, USA

e-mail: trwilli@umich.edu

\section{Destin}

Department of Psychology, University of Michigan,

1012 East Hall, 530 Church Street, Ann Arbor,

MI 48109-1043, USA

e-mail: destin@umich.edu individuals earn more income or attain higher levels of education. Greater income allows for higher and more varied levels of consumption. And more education is linked to a myriad of positive outcomes, including higher lifetime earnings. However, another less frequently discussed possibility is helping people accumulate assets or increase their net worth. Making a shift from debtor to saver or from consumer to investor may allow one to participate more fully in the larger political and economic system while also potentially benefiting the next generation.

Spilerman et al. (1993) argue for the importance of considering wealth or family assets over income as a determinant of life chances. They note that it is much harder for young people to get started in life without material assistance from their family and point out some of the attractive features of wealth that are not shared by earnings. (1) Income from wealth does not require a tradeoff between leisure and work; (2) wealth provides economic security that does not decline with unemployment or end with retirement; (3) wealth can be enjoyed without being consumed and frequently even appreciates in value; (4) but if necessary, wealth can be drawn upon for consumption; and (5) wealth appreciation is often taxed more lightly than labor market income.

Regardless of which socio-economic status indicators one considers, African Americans as a group often face multiple disadvantages and typically fare conspicuously worse than what is found in national averages. African American children are more likely to be poor, less likely to have parents that attain high levels of education, and less likely to reside in households with a high net worth. Thus, if seeking to break cycles of disadvantage, examining opportunities that improve life chances for African American children is likely to provide valuable information that could potentially benefit all children. 
When thinking about issues facing African Americans, many are rightfully concerned about things such as high drop-out rates in urban schools and escalating incarceration rates. However, rather than focusing on problems facing the African American community or comparing Black children to children in other racial and ethnic groups, this paper examines trends within an African American sample to see what aspects of household socio-economic status (SES) seem to promote educational success and the development of human capital over time. The main SES contrast considered in this paper entails distinctions between income and wealth, but the influence of parental education is also taken into account. One reason for this focus is that when examining historical trends (since the post-Civil Rights era), racial disparities in income and education have declined over time, but wealth disparities remain substantial and persistent.

For example, in 1970, only $31.4 \%$ of African Americans age 25 and over had a high school diploma or higher and only $4.4 \%$ had completed a bachelor's degree (U.S. Census Bureau 2006). These numbers have more than doubled to 72.3 and 14.3, respectively, in the year 2000 (U.S. Census Bureau 2006). In fact, nationally in $2005,85.9 \%$ of 18 - to 24-year-old African Americans had earned a high school diploma or general educational development (GED) credential, which is quite similar to the overall national percentage at 87.6 (U.S. Census Bureau 2005). Additionally, the proportion of African Americans 18-24 attending college increased from 19 to $31 \%$ between 1980 and 2000, although they are still much less likely to complete college than other students their age (18\% in 2000 versus 29\%) (Hoffman and Llagas 2003). In addition, a considerable gender disparity exists in college graduation among African Americans, with two-thirds (66\%) of bachelors' degrees being earned by females (Peter and Horn 2005).

Although African Americans continue to have higher unemployment rates and poverty rates than the national average (Fairlie and Sundstrom 1999; DeNavas-Walt et al. 2006), household income has increased over time along with the rest of the country (Farley 1996). In 1970, median African American household earnings were \$5,537 compared with the overall U.S. median of $\$ 8,734$ (63.4\%), and by 2005 this had risen to $\$ 30,858$ for African Americans compared with the U.S. median of $\$ 46,326(66.6 \%)$. Similarly, earnings per African American household member increased from $\$ 4,689$ in 1980 (61\% of overall U.S. earnings) to $\$ 16,224$ in 2000 (66\% of overall U.S. earnings) (U.S. Census Bureau 2007).

Although the historical data are not as good for wealth or net worth, African American households today have much lower levels of wealth than their White counterparts, and this has not changed much since 1967 when such data were first collected (Leigh 2006). In fact, racial wealth gaps grew in the 1980s and 1990s (Wolff 1998). In 2000 the median net worth for African American households was only $\$ 7,500$, compared to $\$ 79,400$ for non-Hispanic White households (Orzechowski and Sepielli 2003). Even when controlling for known class correlates such as income, occupation, and education, wealth differences by race persist (Blau and Graham 1990; Keister 2000; Oliver and Shapiro 2006; Shapiro 2004). In an attempt to evaluate the extent of wealth disparities, Haveman and Wolff (2000) created a measure of "asset-poverty". By their definition, a household is asset-poor if it does not have enough wealth to sustain itself at the poverty line for 3 months. Using this framework, African Americans are more than twice as likely to be asset-poor than non-Hispanic Whites. In 1999, $58 \%$ are asset-poor compared with $20 \%$ for Whites using overall net worth as the measure (Caner and Wolff 2004).

Thus, although educational attainment and, to some extent, income for African Americans have improved over time, major disparities in wealth remain. In addition to the empirical evidence for an entrenched racial wealth gap, there are both practical and theoretical reasons for studying the influence of wealth on educational outcomes and life chances of African American children.

First, in the nation as a whole, regardless of race, wealth is highly unequal. In 2000 , the top $1 \%$ of the wealth distribution held $40 \%$ of wealth while the bottom $90 \%$ of the distribution collectively held only 33\% (Wolff 2001). Not only do African Americans find themselves at the bottom end of this skewed distribution, but mobility over time is unlikely (Diaz-Gimenez et al. 1997; Mulligan 1997; Oliver and Shapiro 2006). In addition to overall wealth inequality, another relevant aspect to consider is intra-racial economic inequality. Disparities between the wealthiest African Americans and the poorest are greater than the disparities within any other race (Lui et al. 2006). This is largely because so many in the African American community (nearly two-thirds) have zero or negative net financial assets, meaning they own nothing of value when equity in a home or cars is excluded (Oliver and Shapiro 2006). So while a few African Americans have been able to take advantage of opportunities to build wealth, the majority of African Americans live paycheck to paycheck with limited economic resources.

A second reason for studying the influence of household wealth on educational outcomes is the possible link to cultural capital and exposure to a broad array of opportunities and activities. Sherraden (1991) theorizes that owning assets has a range of positive benefits: economic, psychological, social, and political. When a poor person with no assets starts on the road to building assets, it can create hope for the future, improve current well-being, and lead others to view the person differently as well (Schreiner and Sherraden 2007; Sherraden 1991). Orr (2003), building 
upon the work of Pierre Bourdieu, links wealth to cultural capital, demonstrating that those with higher net worth are more likely to have children who go to museums and theater and who take lessons, which in turn positively influences academic achievement. In an ethnographic study of middleclass, working class, and poor families, Lareau (2003) comes to a similar conclusion that middle class families are more likely to raise their children to participate in structured activities that develop talents, and, unlike working class and poor children, these children become much better at interacting with and negotiating societal institutions.

And finally, with a specific emphasis on post-secondary education, college is often perceived as unaffordable and unattainable when a household has little or no net worth and modest resources. In field experiments, Destin and Oyserman (in press) find that low-income middle school students who receive information about financial aid show stronger school-focused motivation than students who receive information on high college costs or no information at all about paying for college. These findings suggest that young students' economic assets influence their perceived academic possibilities and level of early engagement in school.

In general, previous studies suggest that not having independently held wealth puts significant stress on African American children and families. Economic insecurity makes planning for the future difficult as well as creates strain within romantic relationships (Conger et al. 1994; Conger et al. 2002; McLoyd 1997). Growing up in households with little or no wealth has a negative impact on children (Conley 1999; Williams Shanks 2007). Specifically, Conley (1999) finds that racial differences in high school graduation, college graduation, and repeating a grade between Whites and African Americans are either no longer significant or dramatically lessen once parental wealth is considered. Shapiro (2004) makes a similar case using qualitative interviews to demonstrate how parents use either personal wealth or money inherited from their parents' wealth to create transformative opportunities for children, particularly via enrollment in better schools. In fact, doubling household net worth has been shown to increase by $8.3 \%$ the probability of going to college after graduating from high school (Conley 2001).

One pathway that seems to connect household wealth and educational outcomes is parental expectations. Zhan and Sherraden (2003) found that mothers who were homeowners or had savings of $\$ 3,000$ or more have higher expectations for their children's educational attainment. Extending this line of inquiry, Zhan (2006) continued to find a positive association between assets and mother's expectations, and between assets and children's education outcomes as measured by PIAT Math scores. Additionally, she finds that about one-third of the relationship between parental assets and children's education could be accounted for by mother's educational expectations for their children.
Building upon such work, this paper tests whether household wealth in early childhood influences parental expectations and educational outcomes for African Americans as they enter young adulthood.

\section{Methods}

Sample

The Panel Study of Income Dynamics (PSID), an ongoing, longitudinal survey of a nationally representative sample of families in the United States since 1968, provides useful data to analyze the effects of wealth on development and educational outcomes for children. Because the survey over-samples low-income and black American families $(n>4000)$, the data may be particularly informative on how wealth shapes outcomes for black children, across the income distribution. The Child Development Supplement (CDS) collected information in 1997 from children in PSID families between the ages of 0 and 12, with a second wave of data collected in 2002. The Transition to Adulthood (TA) survey measured outcomes for young adults who participated in earlier waves of the CDS and were at least 18 years old by 2005 .

\section{Measures}

\section{Wealth}

A measure of total household wealth from 1994 incorporates the sum of a family's net worth on any business or farm, home equity, other real estate, stocks, mutual funds, investment accounts, personal vehicles, other investments, and checking or savings accounts, minus the sum of all debts. For TA participants, the 1994 wealth measure provides a characterization of the family's net worth during their early childhood. A log transformation of wealth is used in regression analyses to ensure a normal distribution.

\section{Income}

Total family income, measured in 1997 , includes all taxable and transfer income of a household and a log transformation of this variable was used as the primary control measure in regression analyses.

\section{Parental Education}

This measure indicates how many years of education have been completed by the head of household; from 1 to 17 (at least some post-graduate work). Parental education was also included as a control measure in regression analyses. 


\section{Parental Expectations}

In 1997 and 2002, CDS parents were asked, "How much schooling do you expect that (CHILD) will complete?" Responses were recorded on an 8-point response scale, from "11th grade or less" to "MD, law, $\mathrm{PhD}$, or other doctoral degree."

\section{Educational Outcomes}

In 2005, TA participants were asked, "Did you graduate from high school, get a GED, or neither?" and "Have you ever attended college?"

\section{Results}

\section{Descriptive Analyses}

In order to illustrate the influence of wealth on parental expectations and actual outcomes for black youth, at varied income levels, we divided the sample into four groups, distinguished by relatively low and high levels of income and wealth. Among black PSID families, the median income in 1997 was $\$ 24,090$ per year, and the median level of wealth in 1994 was $\$ 3,502$. By dividing the sample into four groups, based upon whether families fell above or below these overall medians of income and wealth, we observed mean level differences in expectations and outcomes between groups. Black families with high wealth showed greater parental expectations for a child's educational attainment than families with low wealth, within both income levels. Even amongst low income households, those with high wealth showed greater educational expectations than their low wealth counterparts, and this pattern remained consistent across both CDS time points, (see Figs. 1 and 2).

Higher levels of early household wealth also appeared to benefit actual educational outcomes for black children as they entered young adulthood. Figures 3 and 4 show that black young adults from families with higher early household wealth were more likely to graduate from high school and enroll in college, whether they were from a low or high income background.

\section{Regression Analyses}

Taken together, the descriptive analyses suggest that more wealth was associated with a linear progression of higher parental educational expectations across two time points, leading to actual benefits in educational outcomes for a child. Within each income category, however, the higher wealth households seem more advantaged. As shown in Table 1, "high wealth" groups were characterized by higher income, education, homeownership, and employment rates than "low wealth" groups, even within their respective income categories.

In order to confirm the observed descriptive trends, linear and logistic regressions tested the effects of early household wealth on parental expectations and outcomes for black youth, controlling for other influential characteristics, including income, parental education, and gender. Child and young adult level weights were utilized to ensure nationally representative analyses. As expected, greater wealth significantly predicted higher expected education at both time points as well as a greater likelihood of high
Fig. 1 Effects of early household wealth on parental educational expectations, 1997

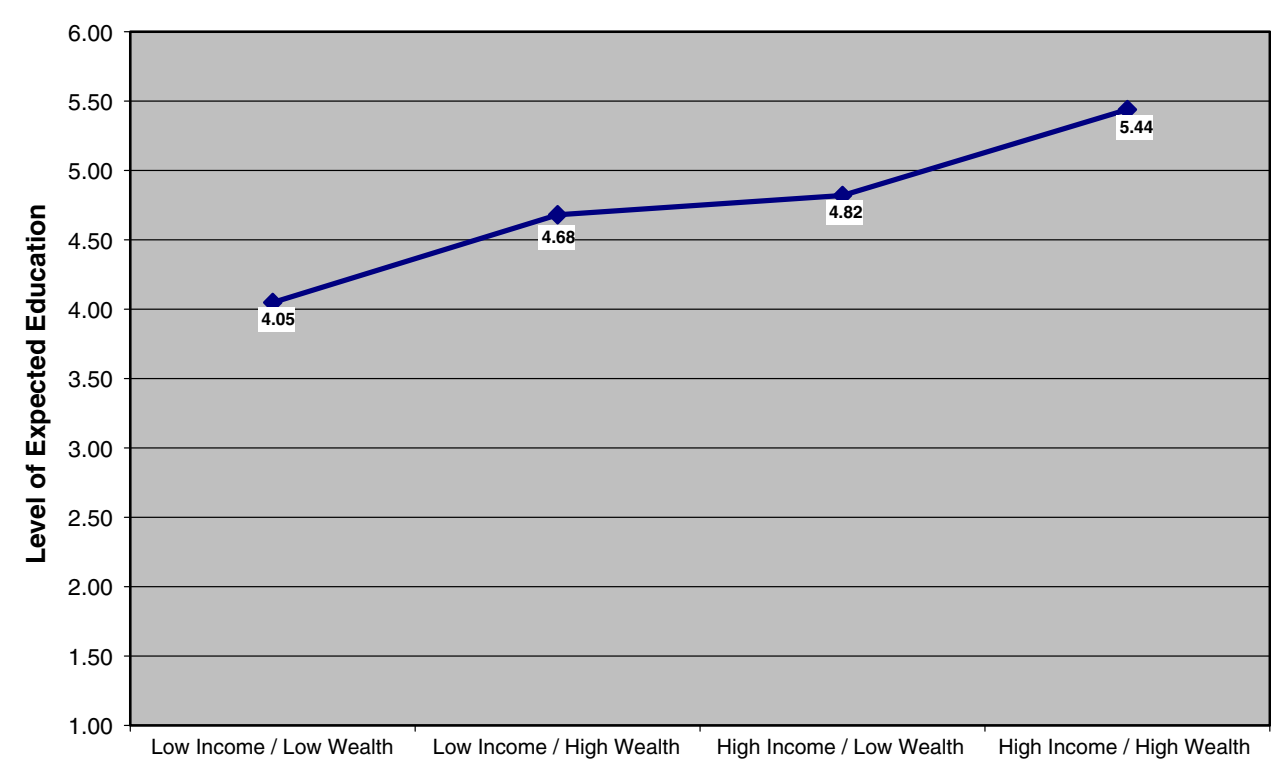


Fig. 2 Effects of early household wealth on parental educational expectations, 2002

Fig. 3 Effects of early household wealth on likelihood of high school graduation/GED, 2005
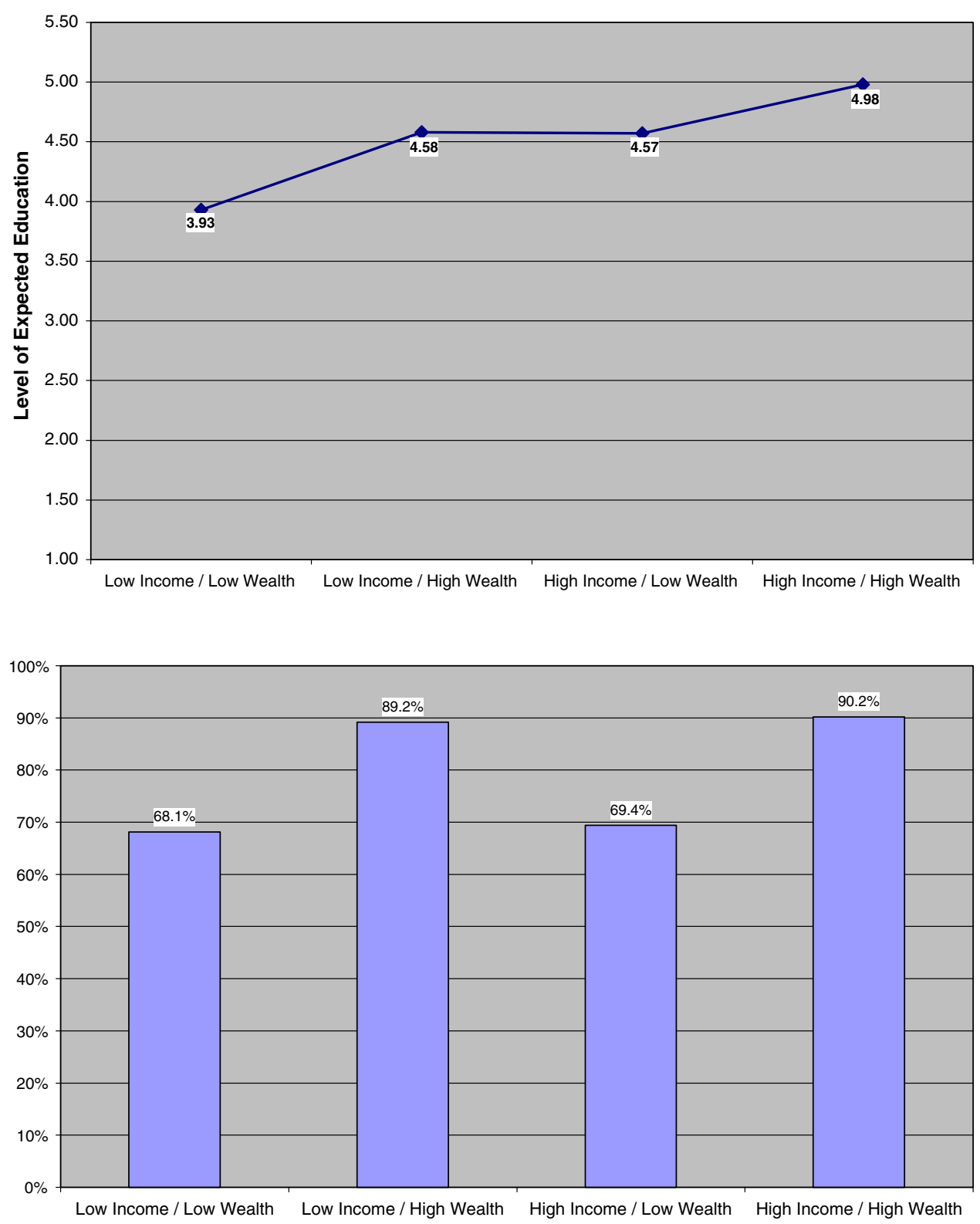

school graduation/GED and college enrollment. In fact, wealth was the most consistently significant predictor of educational expectations and outcomes for black young adults (see Tables 2 and 3).

\section{Discussion}

It is well documented that income poverty has negative consequences for children, but there has been healthy debate around how strong intergenerational correlations actually are and whether simply providing households with additional income might improve child outcomes (Bowles et al. 2005; Duncan and Brooks-Gunn 1997; Mayer 1997). This same level of debate has not yet been had with respect to household wealth. This is partially because data have not yet been collected over a long enough period with appropriate samples. Moreover, the relevant measure may not be just parental net worth, but how much is actually transferred, which would entail accounting for gifts, inter-vivo transfers, and bequests upon death (Bowles et al. 2005). However, if the initial findings from the present study are supported in more complex longitudinal models, our results suggest that household wealth may serve as a protective factor or at least a buffer for children, irrespective of income level. Perhaps being poor with respect to income is less detrimental if the household has at least some assets or a modest net worth.

Our analyses show that household wealth positively correlates with both parental expectations for a child's 
Fig. 4 Effects of early household wealth on likelihood of college enrollment, 2005

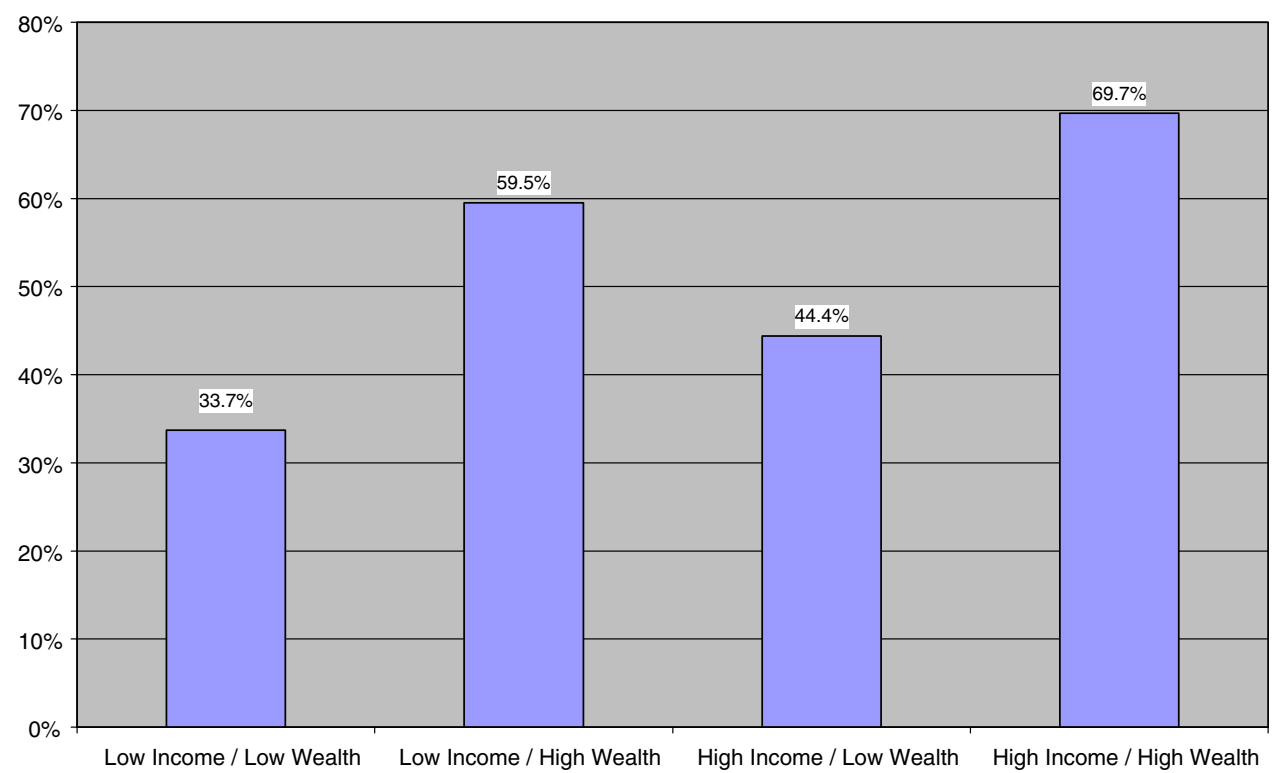

Table 1 Selected characteristics of income/wealth groups

\begin{tabular}{|c|c|c|c|c|c|c|c|}
\hline & $N$ & Percent & $\begin{array}{l}\text { Median } \\
\text { Income (\$) }\end{array}$ & $\begin{array}{l}\text { Median } \\
\text { Wealth (\$) }\end{array}$ & $\begin{array}{l}\text { Years } \\
\text { Education }\end{array}$ & $\begin{array}{l}\text { Homeowners } \\
(\%)\end{array}$ & $\begin{array}{l}\text { Unemployed } \\
(\%)\end{array}$ \\
\hline Low income/low wealth & 1543 & 34.4 & 10,034 & 0 & 11.30 & 12.0 & 16.7 \\
\hline Low income/high wealth & 702 & 15.6 & 14,000 & 22,000 & 11.63 & 56.7 & 9.0 \\
\hline High income/low wealth & 702 & 15.6 & 35,000 & 0 & 11.99 & 43.8 & 9.5 \\
\hline High income/high wealth & 1546 & 34.4 & 47,424 & 33,100 & 12.60 & 74.3 & 8.5 \\
\hline Total sample & 4493 & 100.0 & 24,090 & 3,502 & 11.88 & 46.2 & 11.2 \\
\hline
\end{tabular}

Table 2 Linear regression effects of wealth on parental expectations

\begin{tabular}{lllll}
\hline & $B$ & St. error & $p$ & Adjusted $R^{2}$ \\
\hline Expected education 1997 & & & & .195 \\
Log income & .217 & .083 & .001 & \\
Parental education & .218 & .030 & .001 & \\
Gender & .101 & .136 & .002 & \\
Log wealth & .160 & .040 & .001 & \\
Expected education 2002 & & & & .095 \\
Log income & .059 & .090 & .157 & \\
Parental education & .189 & .033 & .001 & \\
Gender & .147 & .147 & .001 & \\
Log wealth & .150 & .045 & .001 & \\
\hline
\end{tabular}

Standardized coefficients are reported

education as well as actual educational outcomes. A strength of our study is that these results come from natural observation in a national dataset. However, although the timing is right in that wealth was measured in 1994 before later expectations, high school graduation, and college enrollment, it is possible that other family and contextual
Table 3 Logistic regression effects of wealth on young adult outcomes

\begin{tabular}{|c|c|c|c|c|c|}
\hline & $B$ & St. error & Wald & $p$ & Pseudo $R^{2}$ \\
\hline $\begin{array}{l}\text { High school graduation/ } \\
\text { GED } 2005\end{array}$ & & & & & .011 \\
\hline Log income & .246 & .181 & 1.851 & .174 & \\
\hline Parental education & .058 & .045 & 1.679 & .195 & \\
\hline Gender & .365 & .235 & 2.414 & .120 & \\
\hline Log wealth & .281 & .082 & 11.867 & .001 & \\
\hline College enrollment 2005 & & & & & .039 \\
\hline Log income & .096 & .103 & .879 & .348 & \\
\hline Parental education & .067 & .025 & 7.480 & .006 & \\
\hline Gender & .518 & .142 & 13.329 & .001 & \\
\hline Log wealth & .156 & .049 & 10.225 & .001 & \\
\hline
\end{tabular}

Unstandardized coefficients are reported

variables not specified in the model could have influenced results. There may be something about parental abilities and motivations or the school and neighborhood environments that is closely associated with household wealth in 
the sample. Some of these possible mediating variables are hypothesized or examined in other studies (Lareau 2003; Shapiro 2004). It would be difficult to test the relevant mediators in similar detail using PSID/CDS data because there is little qualitative data. In addition, the original CDS sample covers a wide range of ages, which sometimes necessitates distinct parenting and home environment scales, with only a portion of youth yet old enough to have completed relevant educational milestones. Thus, the present study only focused on direct effects of SES variables although we recognize that understanding underlying processes would better clarify relationships and possible levers for intervention.

Nevertheless, an important question is whether it is even possible to help households build assets and increase their net worth over time. If so, this could be another option in the arsenal to lessen the consequences of intergenerational disadvantage. In addition, even those parents or caregivers unlikely to attain substantive increases in their income or education might potentially respond to options that increase their net worth.

Another interesting implication from these analyses is that the level of wealth need not be large to detect a positive influence on child outcomes. Among this African American sample, the median cutoff for net worth was only $\$ 3500$. In practical terms, this amount could be reached fairly easily by taking small steps such as maintaining a balance of several hundred dollars in a savings account, owning the title to one's vehicle, and paying off a few debts. In reality, however, going from having zero or negative net worth to maintaining even a modest amount of wealth over time might entail non-trivial changes in attitudes and behavior.

There is some research on factors that help predict a household's level of asset accumulation, which encompasses its overall net worth (Beverly et al. 2008). Although individual constructs such as financial literacy, social networks, and psychological variables are important, along with intergenerational and interhousehold transfers such as bequests, institutional constructs tend to have the strongest effects (Beverly et al. 2008; Sherraden 1991). These purposefully created policies, programs, products, and services-identified as institutional constructs-shape opportunities for asset building and make it more likely that individuals will save and invest. Seven institutional constructs have been studied: access, information, incentives and disincentives, facilitation, expectations, restrictions, and security (Beverly and Sherraden 1999; Beverly et al. 2008). These findings would suggest specific supports that allow wider eligibility, offer relevant education, provide progressive subsidies or match incentives, facilitate direct deposits, set expectations, restrict access to funds, and reduce risk.
In the last decade, many new programs have been created that offer asset building opportunities to households with low incomes. One popular product is the Individual Development Account or IDA. IDAs are subsidized accounts set up similar to $401 \mathrm{~K}$ plans, but targeted to the poor, encouraging savings by offering a match for personal deposits (typically $\$ 2$ for every $\$ 1$ saved). The use of IDAs is typically restricted to purchasing a home, paying for post-secondary education, or starting a small business. These accounts were designed with a policy objective in mind-to demonstrate that poor people could save if provided an opportunity (Schreiner and Sherraden 2007).

And the poor can save-even former welfare recipients and those with very low income. In a national demonstration research study, 2,350 low-income participants were offered IDA accounts. As summarized by Schreiner and Sherraden (2007), 52\% saved over $\$ 100$ and accumulated a net IDA savings of $\$ 32.44$ per month. The average participant saved about $\$ 1$ for every $\$ 2$ that could have been matched and made a deposit about 1 of every 2 months in which an IDA was open. With an average match rate of 1.88:1, the average participant accumulated \$1,609 in IDAs (Schreiner and Sherraden 2007). Making and attaining savings goals might also increase the belief that other personal and familial goals are attainable. In qualitative interviews, IDA participants expressed increased feelings of security, greater self-confidence, an increased ability to set and achieve goals, a greater sense of responsibility, and increased hope for the future (Sherraden et al. 2005). Many of these same participants suggest that their children are an important motivation for saving (Sherraden et al. 2005).

A similar research demonstration is underway to test the efficacy of offering progressively matched accounts specifically targeted toward saving for children. The Saving for Education, Entrepreneurship and Downpayment (SEED) initiative began in 2003 and is now a 12-year research endeavor taking place in community sites throughout the country, two of which will test impact assessment with experimental designs. As of June 30, 2007, 1,253 SEED accounts had been opened with a total accumulation of 1.6 million dollars and an average savings per child of $\$ 1,318$ (Mason et al. 2007). Although there is still much to be learned as research results unfold, parents of young children as well as older youth with accounts initially had positive perceptions of the program and its potential benefits (Johnson et al. 2008; Scanlon et al. 2007).

After a phase of sustained growth between 1994 and 2005, where homeownership overall as well as among African Americans increased (Gramlich 2007), the United States has now entered a period of economic decline. At a time of record foreclosures, depreciating home values, a plummeting stock market, and extreme economic uncertainty, many are facing a loss of net worth. But as in 
previous periods, African Americans are likely to fare worse. Given that foreclosures are concentrated in low-tomoderate income and minority communities, that a disproportionate share of sub-prime loans with onerous terms went to African Americans (even those with good credit scores and high income), that black households are more dependent on their homes with a larger proportion of average net worth in home equity, and that many have had a legitimate opportunity to build wealth for only one generation, losses to African American families will be high (Oliver and Shapiro 2008). If there were ever a time for households to become less dependent on credit and borrowing and more disposed to saving and building assets, it would be now. Thus, any policies or supports that offer opportunities to generate wealth or provide a mechanism for some form of universal accounts for children might be particularly salient for the circumstances faced by African American families.

Of course, helping households to build assets is not a panacea to all problems African American children face. However, the persistent racial disparities that exist in wealth have hampered sustained economic prosperity, even among African Americans that might otherwise appear successful (with higher income or education). Whether driven primarily by poor choices or by a combination of discriminatory policies and a simple lack of good information and role models, having little or no wealth makes raising children more stressful. If subsequent research concurs that changing this reality could positively impact educational attainment, it is worth considering as a policy option. A focus on reducing racial wealth disparities might even become the next frontier for civil rights.

\section{References}

Beverly, S., \& Sherraden, M. (1999). Institutional determinants of saving: Implications for low-income households and public policy. Journal of Socio-economics, 28(4), 457-473.

Beverly, S., Sherraden, M., Cramer, R., Williams Shanks, T., Nam, Y., \& Zhan, M. (2008). Determinants of asset holding. In S.-M. McKernan \& M. Sherraden (Eds.), Asset building and lowincome families (pp. 89-151). Washington, DC: Urban Institute Press.

Blau, F. D., \& Graham, J. W. (1990). Black-white differences in wealth and asset composition. Quarterly Journal of Economics, 105(2), 321-339.

Bowles, S., Gintis, H., \& Osborne Groves, M. (2005). Unequal chances: Family background and economic success. New York: Russell Sage Foundation.

Caner, A., \& Wolff, E. (2004). Asset poverty in the United States, 1984-1999: Evidence from the panel study of income dynamics. Review of Income and Wealth, 50(4), 493-518.

Conger, R. D., Ge, X., Elder, G., Lorenz, F., \& Simons, R. (1994). Economic stress, coercive family process, and developmental problems of adolescents. Child Development, 65(2), 541-561.
Conger, R. D., Wallace, L. E., Sun, Y., Simons, R. L., McLoyd, V. C., \& Brody, G. H. (2002). Economic pressure in African American families: A replication and extension of the family stress model. Developmental Psychology, 38, 179-193.

Conley, D. (1999). Being black, living in the red: Race, wealth, and social policy in America. Berkeley, CA: University of California Press.

Conley, D. (2001). Capital for college: Parental assets and postsecondary schooling. Sociology of Education, 74(1), 59-72.

DeNavas-Walt, C., Proctor, B., \& Lee, C. (2006). Income, poverty and health insurance coverage in the United States: 2005. Washington, DC: U.S. Census Bureau.

Destin, M., \& Oyserman, D. (in press). From assets to school outcomes. Psychological Science.

Diaz-Gimenez, J., Quadrini, V., \& Rios-Rull, J.-V. (1997). Dimensions of inequality: Facts on the U.S. distributions of earnings, income, and wealth. Quarterly Review, 21(2), 3-21.

Duncan, G., \& Brooks-Gunn, J. (1997). Consequences of growing up poor. New York: Russell Sage Foundation.

Fairlie, R., \& Sundstrom, W. (1999). The emergence, persistence, and recent widening of the racial unemployment gap. Industrial and Labor Relations Review, 52, 252.

Farley, R. (1996). The new American reality: Who we are, how we got here, where we are going. New York: Russell Sage Foundation.

Gramlich, E. M. (2007). Subprime mortgages: America's latest boom and bust. Washington, DC: Urban Institute Press.

Haveman, R., \& Wolff, E. N. (2000). Who are the asset poor? Levels, trends and composition, 1983-1998. St. Louis: Center for Social Development, Washington University.

Hoffman, K., \& Llagas, C. (2003). Status and trends in the education of blacks (NCES 2003-034). Washington, DC: U.S. Department of Education, National Center for Education Statistics, Government Printing Office.

Johnson, T., Kim, J., \& Adams, D. (2008). Mapping the perspectives of low-income parents in a Children's College Savings Account program: Individual and institutional factors. SEED research report. Lawrence, KS: School of Social Welfare, University of Kansas.

Keister, L. A. (2000). Race and wealth inequality: The impact of racial differences in asset ownership on the distribution of household wealth. Social Science Research, 29(4), 477-502.

Lareau, A. (2003). Unequal childhoods: Class, race, and family life. Berkeley, CA: University of California Press.

Leigh, W. A. (2006). Wealth measurement: Issues for people of color in the United States. In J. Nembhard \& N. S. Chiteji (Eds.), Wealth accumulation and communities of color in the United States (pp. 23-66). Ann Arbor: University of Michigan Press.

Lui, M., Robles, B., Leondar-Wright, B., Brewer, R., \& Adamson, R. (2006). The color of wealth: The story behind the U.S. racial wealth divide. New York: New Press.

Mason, L. M., Clancy, M., et al. (2007). SEED account monitoring research: Participants and savings outcomes at June 30, 2007. St. Louis, MO: Center for Social Development, Washington University.

Mayer, S. E. (1997). What money can't buy: Family income and children's life chances. Cambridge, MA: Harvard University Press.

McLoyd, V. C. (1997). The impact of poverty and low socioeconomic status on the socioemotional functioning of African-American children and adolescents: Mediating effects. In R. Taylor \& M. Wang (Eds.), Social and emotional adjustment and family relations in ethnic minority families. Hillsdale, NJ: Lawrence Erlbaum.

Mulligan, C. B. (1997). Parental priorities and economic inequality. Chicago: University of Chicago Press. 
Oliver, M. L., \& Shapiro, T. M. (2006). Black wealth/white wealth: A new perspective on racial inequality (10th ed.). New York: Routledge.

Oliver, M. L., \& Shapiro, T. M. (2008, October). Sub-prime as a black catastrophe. The American Prospect, 19(10). Available at: http:// www.prospect.org/cs/articles?article=sub_prime_as_a_black_ catastrophe.

Orr, A. (2003). Black-white differences in achievement: The importance of wealth. Sociology of Education, 76(4), 281-304.

Orzechowski, S., \& Sepielli, P. (2003). Net worth and asset ownership of households: 1998 and 2000. Washington, DC: U.S. Census Bureau.

Peter, K., \& Horn, L. (2005). Gender differences in participation and completion of undergraduate education and how they have changed over time (NCES 2005-169). Washington, DC: U.S. Department of Education, National Center for Education Statistics, Government Printing Office.

Scanlon, E., Buford, A., \& Dawn, K. (2007). Matched savings accounts: A study of youth perceptions of program and account designs. SEED research report. Lawrence, KS: School of Social Welfare, University of Kansas.

Schreiner, M., \& Sherraden, M. (2007). Can the poor save? Saving and asset building in individual development accounts. New Brunswick, NJ: Transaction Publishers.

Shapiro, T. M. (2004). The hidden cost of being African American: How wealth perpetuates inequality. New York: Oxford University Press.

Sherraden, M. W. (1991). Assets and the poor: A new American welfare policy. Armonk, NY: M.E. Sharpe.

Sherraden, M., Moore McBride, A., Johnson, E., Hanson, S., Ssewamala, F. M., \& Shanks, T. R. (2005). Saving in lowincome households: Evidence from interviews with participants in the American Dream Demonstration. St. Louis, MO: Center for Social Development, Washington University.
Spilerman, S., Lewin-Epstein, N., \& Semyonov, M. (1993). Wealth, intergenerational transfers, and life chances. In J. S. Coleman, A. B. Sorensen, \& S. Spilerman (Eds.), Social theory and social policy: Essays in honor of James S. Coleman (pp. 165-186). Westport, CT: Praeger.

U.S. Census Bureau. (2006). A half-century of learning: Historical statistics on educational attainment in the United States, 1940 to 2000 (Census 2000 PHC-T-41). Retrieved December 12, 2008 from http://www.census.gov.

U.S. Census Bureau, Current Population Survey. (2005). Annual social and economic supplement. Retrieved December 12, 2008 from http://www.census.gov.

U.S. Census Bureau, Current Population Survey. (2007). Annual social and economic supplement. Historical income tablesHousehold. Retrieved December 12, 2008 from http://www. census.gov.

Williams Shanks, T. R. (2007). The impact of household wealth on child development. Journal of Poverty, 11(2), 93-116.

Wolff, E. N. (1998). Recent trends in the size and distribution of household wealth. Journal of Economic Perspectives, 12(3), $131-150$.

Wolff, E. N. (2001). Recent trends in wealth ownership, from 1983 1998. In T. M. Shapiro \& E. N. Wolff (Eds.), Assets for the poor: The benefits of spreading asset ownership (pp. 34-73). New York: Russell Sage Foundation.

Zhan, M. (2006). Assets, parental expectations and involvement, and children's educational performance. Children and Youth Services Review, 28(8), 961-975.

Zhan, M., \& Sherraden, M. (2003). Assets, expectations, and children's educational achievement in female-headed households. Social Service Review, 77(2), 191-211. 